\title{
Kinetics of the Enzymatic Hydrolysis of Sweet Cassava Starch, Bitter Cassava, and Gadung (Dioscorea hispida Dennst) Flours at Low Temperature
}

\author{
Hargono Hargono, Bakti Jos, Andri Cahyo Kumoro* \\ Department of Chemical Engineering, Faculty of Engineering, Diponegoro University \\ Jl. Prof. Soedarto, SH, Kampus Undip Tembalang, Semarang 50275, Indonesia
}

Received: 21 ${ }^{\text {st }}$ November 2016; Revised: $6^{\text {th }}$ February 2017; Accepted: $18^{\text {th }}$ February 2017

\begin{abstract}
Starch is a potential substrate for this purpose, but the extra cost is needed to hydrolyze it into reducing sugar. As an alternative to the expensive and energy demanding conventional hydrolysis process, the low-temperature hydrolysis is being studied. Granular starch hydrolyzing enzyme (GSHE) was used in the process to degrade starch into reducing sugar at $30{ }^{\circ} \mathrm{C}$ and $\mathrm{pH} 4$. The substrates included sweet cassava starch, bitter cassava, and gadung (Dioscorea hispida Dennst) flours. Starch concentrations studied were in the range 50-400 g/L, respectively, while the concentration of enzyme was maintained at $1.5 \%(\mathrm{w} / \mathrm{w})$. The optimum productivity of reducing sugar $\left(Q_{r s}\right)$ of sweet cassava starch, bitter cassava, and gadung flours were 4.11, 3.10, and 0.52 (g/L.h), respectively. The Michaelis-Menten constants $\left(K_{m}\right)$ for these three substrates were determined as $139.84 \mathrm{~g} / \mathrm{L}, 141.43 \mathrm{~g} / \mathrm{L}$, and $140.92 \mathrm{~g} / \mathrm{L}$ for sweet cassava starch, bitter cassava, and gadung flours, respectively. Increasing of cyanide concentration during hydrolysis process of sweet cassava starch, bitter cassava, and gadung flours decreased $V_{\max }$, significantly. Based on Lineweaver-Burk plot for sweet cassava starch, bitter cassava, and gadung flours (50-400 g/L) with the cyanide concentration of 42,168 , and $176 \mathrm{mg} / \mathrm{kg}$, can be classified as noncompetitive inhibition with $\mathrm{K}_{\mathrm{I}}$ value of 0.0317. Copyright (C) 2017 BCREC Group. All rights reserved.
\end{abstract}

Keywords: GSHE; Low temperature hydrolysis; Inhibition kinetics; Reducing sugar

How to Cite: Hargono, H., Jos, B., Kumoro, A.C. (2017). Kinetics of the Enzymatic Hydrolysis of Sweet Cassava Starch, Bitter Cassava and Gadung (Dioscorea hispida Dennst) Flours at Low Temperature. Bulletin of Chemical Reaction Engineering \& Catalysis, 12 (2): 256-262 (doi:10.9767/bcrec.12.2.808.256262)

Permalink/DOI: http://dx.doi.org/10.9767/bcrec.12.2.808.256-262

\section{Introduction}

Cassava is a starchy root crop that is grown almost entirely in the low land tropics. Cassava roots are an excellent source of carbohydrates. The roots are very starchy, and the young leaves are a good source of protein. As a defense

* Corresponding Author.

E-mail: andrewkomoro@che.undip.ac.id (Kumoro, A.C.)

Telp.: +6224-7460058; Fax.: +6224-76480675 mechanism against attack by a predator, cassava produces two cyanogenic glucosides, linamarin, and a small of lotaustralin [1]. Cassava cultivars can be classified into high cyanide (bitter) and low cyanide (sweet) [2]. Lambri et al. [3] reported that the total cyanide content of cassava root for sweet white and bitter white was 374 and $442 \mathrm{mg} / \mathrm{kg}$ (d.w), respectively. Djazuli and Bradbury [4] reported of 14 samples of cyanogens content of cassava starch in Indonesia, obtained by the acid hydrolysis method 
[5]. The maximum value of cyanogens content in cassava starch and cassava flours were 12 ppm and $149 \mathrm{ppm}$. Toxicity of cyanide in the tubers depending on the form of granules. The degree of toxicity of cyanogens in starch $<$ chip $<$ flour. The World Health Organization (WHO) has set the safe level of cyanogens in cassava flour at $10 \mathrm{ppm}$ [5].

Bitter Yam (Dioscoreae hispida Dennst) is commonly found in secondary forest, grows under shaded areas or near sreams, and locally known as gadung [6]. However, some studies have also pointed out that this yam tuber also contains some toxic compound, which can seriously impact the health of the people who consume the tuber. Among the yam species, Dioscoreae hispida was considered as one of the most underutilized species because of the presence of poisonous alkaloids known as dioscorin and cyanogens as anti-nutrient [7].

Recently, inhibitory kinetics of the granular starch hydrolyzing enzyme (GSHE) by inhibitor have not fully studied. The effect of cyanide on GSHE activity has been studied. Adam [8] reported that cyanide, probably in the undissociated acid form, it was shown that cyanide is a weak competitive inhibitor of green bean lipoxygenase. Parashar and his coworker [9] reported that the toxicity of cyanide is hitherto attributed to bind to the heme proteins active site and thereby inhibit their activity. The reason for this probably lies in the presence of components in various preparations which react with cyanide and reduce its effectiveness as GSHE inhibitor.

The objective of this study is to investigate the effect of cyanide in the sweet cassava starch, bitter cassava, and gadung flours on the activity of GSHE. Competitive, noncompetitive, and uncompetitive inhibition mathematical models were applied to quantify the inhibitory effect of this cyanogenic compound.

\section{Materials and Methods}

\subsection{Materials}

\subsubsection{Cassava and gadung tubers}

Ten months old of bitter cassava was called Pandemir (Manihot glaziovii) and the sweet cassava (Manihot esculenta) tubers were obtained from Wonogiri district in Indonesia, while gadung tuber with 9 months old was obtained in Godean district in Indonesia.

\subsubsection{Sweet cassava starch extraction}

The sweet cassava tuber was selected, washed, peeled, and grated to finer particles. The starch was extracted from the grated pulp by sieving while the fiber was retained. The fiber retained was repeatedly washed for at least four times with distilled water on the cloth screen. The fiber, still contains some unrefined starch, was pressed by hand and dried in the sun. The powdery starch was then stored in an air tight container to prevent contamination and moisture.

\subsubsection{Bitter cassava and gadung flours extrac-} tion

The tuber of bitter cassava and gadung were washed to remove dirt, peeled, sliced, airdried, milled, and sieved to obtain 100 mesh size raw flour. Analysis of physicochemical properties of the sweet cassava starch, bitter cassava, and gadung flours are presented in Table 1.

\subsubsection{Reagents}

Cyanide (as Potassium cyanide) was the product by MERCK, potassium sodium tartrate tetrahydrate and 3,5-dinitrosalicylic acid (Sigma-Aldrich), $\mathrm{NaOH}$ (98\%, Merck), $\mathrm{Na}_{2} \mathrm{SO}_{3}$ (98.5 \%, Merck), $\mathrm{H}_{2} \mathrm{SO}_{4}(98.5 \%$, Merck), sodium acetate buffer (Sigma-Aldrich), glucose (99.5 \%, Sigma-Aldrich).

\subsubsection{Enzyme}

The enzymes were a granular starch hydrolyzing enzymes, Stargen ${ }^{\mathrm{TM}}$ 002, which is a mixture of $\alpha$-amylase and glucoamylase produced by Genencor (Palo Alto, USA). The activity and optimal $\mathrm{pH}$ range declared by the producer are 570 GAU g/L and 4.0-4.5, respectively. A Glucoamylase Unit (GAU) is the amount of enzyme that releases $1 \mathrm{~g}$ of reducing sugar calculated as glucose per hour from the soluble

Table 1. Properties of sweet cassava starch, bitter cassava, and gadung flours

\begin{tabular}{lcccc}
\hline Parameters & $\begin{array}{c}\text { native cassava } \\
\text { starch (control) }\end{array}$ & $\begin{array}{c}\text { sweet cassava } \\
\text { starch }\end{array}$ & $\begin{array}{c}\text { bitter cassava } \\
\text { flour }\end{array}$ & gadung flour \\
\hline Moisture content (\%), w/w & 10.22 & 10.25 & 10.80 & 12.2 \\
Starch (\%), w/w & 85.84 & 83.12 & 82.70 & 26.38 \\
Total cyanide, $\mathrm{mg} / \mathrm{kg}$ & 0 & 42 & 168 & 176 \\
\hline
\end{tabular}


starch substrate under the conditions of the assay [10].

\subsection{Reversible inhibition}

One common type of reversible inhibition is called competitive [11]. Three modes of reversible enzyme inhibition can be distinguished by their effects on different inhibitor. Doublereciprocal plot data collected in the presence of different concentration of an inhibitor reveal the value of $K_{I}$, the dissociation constant of the inhibitor from the enzyme. The inhibition effect of $K_{I}$ on the reaction kinetics is reflected on the normal $K_{m}$ and $V_{\max }$ observed in LineweaverBurk plots [12]. The rate equations of three simple types of inhibition [13] are:

Competitive inhibition:

$$
v_{0}=\frac{v_{\max }[S]}{K_{m}\left[1+\frac{I}{K_{I}}\right]+[S]}
$$

Noncompetitive inhibition:

$$
v_{0}=\frac{v_{\max }[S]}{\left(K_{s}+S\right)\left[1+K_{I}\right]}
$$

Uncompetitive inhibition:

$$
v_{0}=\frac{v_{\max }[S]}{K_{m}+[S]\left[1+\frac{1}{K_{I}}\right]}
$$

and in the double-reciprocal equation becomes:

Competitive inhibition:

$$
\frac{1}{v_{0}}=\frac{K_{m}}{v_{\max }}\left\{1+\left[\frac{1}{K_{I}}\right]\left[\frac{1}{S}\right]\right\}+\frac{1}{v_{\max }}
$$

Noncompetitive inhibition:

$$
\frac{1}{v_{0}}=\frac{K_{m}}{v_{\max }}\left[\frac{1}{S}\right]+\frac{1}{v_{\max }}\left(1+\frac{1}{K_{I}}\right)
$$

Uncompetitive inhibition:

$$
\frac{1}{v_{0}}=\frac{K_{m}}{v_{\max }}\left\{1+\left[\frac{1}{K_{I}}\right]\left[\frac{1}{S}\right]\right\}+\frac{1}{v_{\max }}\left\{1\left[\frac{1}{K_{I}}\right]\right\}
$$

where $v_{0}$ is initial velocity (g/L.h), $V_{\max }$ is maximum reaction velocity $(\mathrm{g} / \mathrm{L} . \mathrm{h}),[S]$ is substrate concentration remaining at time $t(\mathrm{~g} / \mathrm{L}), K_{m}$ is Michaelis-Menten constants, $K_{I}$ is inhibitor constant from the enzyme, and $[I]$ is inhibitor concentration $(\mathrm{mg} / \mathrm{L})$.

The plot of the $\left[1 / v_{0}\right]$ versus $1 /[S]$ at different cyanide in tubers was constructed to confirm the reversibility of cyanide mediated inhibition, the straight line all passed through the origin, and the slope was decreased with increasing concentration of inhibitor [11].

\subsection{Determination of inhibitory type}

The double-reciprocal plot offers and easy way of determining whether an enzyme inhibitor is competitive, noncompetitive or uncompetitive. Figure 1 show profile of the LineweaverBurk plot for determination of three common types of reversible kinetic constants $[11,13]$.

\subsection{Enzymatic hydrolysis}

The sweet cassava starch, biter cassava and the gadung flours slurries of 50,100, 150, 200, $250,300,350$, and $400 \mathrm{~g} / \mathrm{L}$ concentration were used in this research. The slurry was adjusted to $\mathrm{pH} 4$ (in $50 \mathrm{mM}$ sodium acetate buffer), and Stargen $^{\mathrm{TM}} 002(1.5 \% \mathrm{v} / \mathrm{w})$ was added, mixed and incubated at a temperature of $80{ }^{\circ} \mathrm{C}$ for 15 $\min$ at $100 \mathrm{rpm}$. The slurry was out cooled to

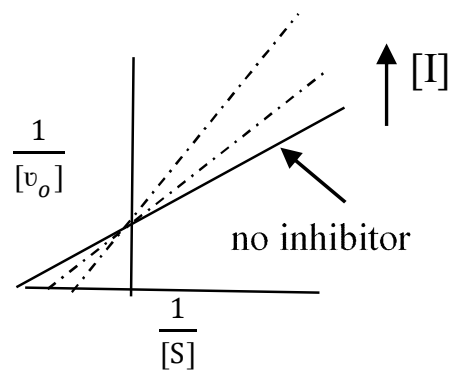

(A)

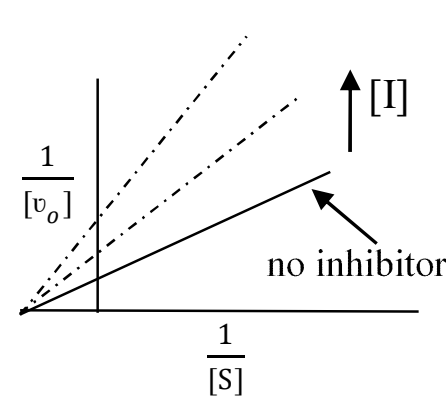

(B)

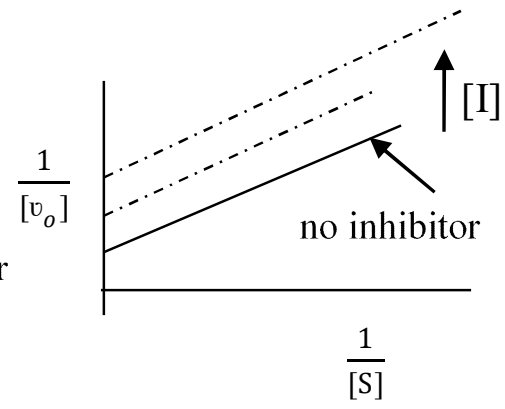

(C)

Figure 1. Lineweaver-Burk plot for (A) competitive inhibition, (B) noncompetitive inhibition, and (C) uncompetitive inhibition 
room temperature $\left(30 \pm 1{ }^{\circ} \mathrm{C}\right)$ and incubation was continued for $24 \mathrm{~h}$. The samples were periodically withdrawn from the flask at $6 \mathrm{~h}$ interval and substantially subjected to reducing sugar. Before the samples were analyzed by a spectrophotometer, they were centrifuged (100 $\mathrm{Hz}, 4^{\circ} \mathrm{C}$, and $10 \mathrm{~min}$ ) to obtain the filtrate.

\subsection{Analytical methods}

The starch content was determined by AQAC method [14]. The water content in cassava starch was determined by standard drying method in an oven at $105{ }^{\circ} \mathrm{C}$ to constant mass [15]. The total cyanide analysis by the acid hydrolysis method [5]. During the cassava starch hydrolysis, the content of reducing sugar was measured using dinitro salicylic acid method [16]. The reagent consisting of an aqueous solution of $1 \%$ 3,5-dinitrosalicylic acid, $0.05 \% \mathrm{Na}$ sulfite, $20 \% \mathrm{Na}-\mathrm{K}$ tartrate, and $1 \% \mathrm{NaOH}$ solution was added in the ratio $3: 1$ to the samples in glass tubes, shaken in incubated in a boiling water bath for $8 \mathrm{~min}$. The reacted samples were cooled in an ice water bath for $5 \mathrm{~min}$, prior to measuring absorbance at $540 \mathrm{~nm}$ by using a UV/visible spectrophotometer (UV-160A, SHIMADZU, Kyoto, Japan). Glucose (0 to $60 \mathrm{~g} / \mathrm{L}$ ) was used as a standard, therefore, reducing sugar concentrations was reported as $\mathrm{g} / \mathrm{L}$.

\subsection{Productivity of reducing sugar $\left(Q_{\mathrm{rs}}\right)$}

The productivity of reducing sugar $\left(Q_{r s}\right)$ in the first hour of hydrolysis, which is calculated by equation (7):

$$
Q_{r s}(t)=\frac{C_{r s, t}-C_{r s, t=0}}{t}
$$

where $Q_{r s}$ is the productivity of reducing sugar (g/L.h), $C_{r s, t}$ is the mass concentration of remaining reducing sugar $(\mathrm{g} / \mathrm{L})$ when productivity is calculated, $C_{r s, t=0}$ is the mass concentration of reducing sugar before the enzyme are added to the medium, and $t(\mathrm{~h})$ is the time for which for productivity is calculated, being $t=0$ defined as the moment when the enzyme blend are added to the medium [17].

\subsection{Determination of kinetic parameters}

The amount of reducing sugar at different substrate concentration $[S]$ is plotted as a function of time. The initial velocity of sweet cassava starch, a bitter cassava and gadung flours at a concentration of $50-400 \mathrm{~g} / \mathrm{L}$ is determined from the slope of curve the relationship between reducing sugar versus time at beginning of a reaction [11]. The characteristic con- stant $V_{\max }$ and $K_{m}$ can be determined experimentally by incubating the enzyme with different concentrations substrate. The results can be plotted as a graph of initial of velocity, vo against initial concentration of substrate $\left[S_{o}\right]$. Based on equation (4-6) when we plot of $1 / v_{0}$ versus $1 /\left[S_{0}\right]$ a straight line is obtained $Y$ intercept (for determining $V_{\max }$ ) and $X$ intercept (for determining $K_{m}$ ) as described in Figure $1[11,13]$.

\subsection{Determination of the inhibitor con- stants for a noncompetitive inhibitor}

The value of dissociation constant $\left(K_{I}\right)$ can be determined as the intercept of the slope by plotted as a function of inhibitor concentration $[I]$. For this plot, the $x$-intercept is equal to $-K_{I}$ [18].

\section{Results and Discussion}

3.1. Determination of reducing sugars by GSHE from sweet cassava starch, bitter cassava, and gadung flours hydrolysis and determination of productivity of reducing sugar

The reducing sugars obtained from sweet cassava starch, bitter cassava flour, and gadung flour by GSHE with concentration of $1.5 \%(\mathrm{w} / \mathrm{w})$, and starch concentration of 200 $\mathrm{g} / \mathrm{L}$ at $30^{\circ} \mathrm{C}$ and $\mathrm{pH} 4$ during hydrolyzing time of 0 to $24 \mathrm{~h}$ are given in Figure 2. At time of 0

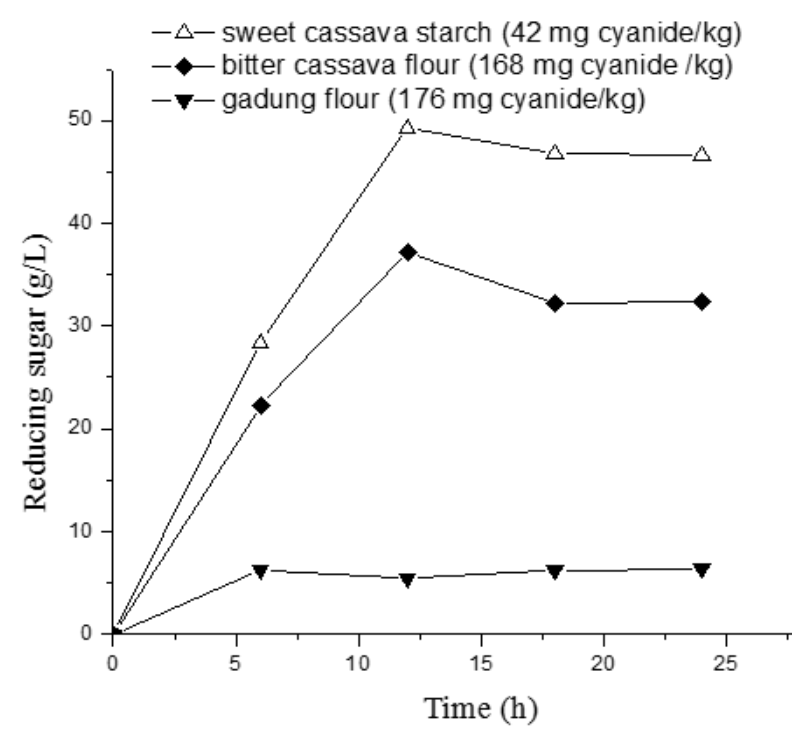

Figure 2. Hydrolysis profile of sweet cassava starch, bitter cassava, and gadung flours at substrate concentration of $200 \mathrm{~g} / \mathrm{L}$, enzyme concentration of $1.5 \%(\mathrm{w} / \mathrm{w}), \mathrm{pH} 4$, and temperature of $30^{\circ} \mathrm{C}$ 
to $24 \mathrm{~h}$, product of the reducing sugar of sweet starch was higher than the bitter and gadung flours. At hydrolyzing time of $12 \mathrm{~h}$, a maximum reducing sugar (sweet cassava starch of 40.98, bitter cassava flour of 37.21 , and gadung flour of $5.36 \mathrm{~g} / \mathrm{L})$, respectively, is appeared. Furthermore after 12 hours, the hydrolysis of both types of cassava decelerated, and then followed by constant rate at 18 to $24 \mathrm{~h}$. Based on eq. (7), the optimum productivity of reducing sugar $\left(Q_{r s}\right)$ of sweet cassava starch, bitter cassava, and gadung flours were 4.11, 3.10, and 0.52 (g/L.h), respectively. The starch content in gadung tuber is much lower than sweet cassava and bitter cassava tubers, so the cyanide content in the gadung tuber is much higher than sweet cassava and bitter cassava tubers, as a consequence the cyanide may inhibit the enzyme leading to decrease of enzyme activity. Shanavas et al. [19] reported the reducing sugar formed from cassava starch by varying level of Stargen, at $\mathrm{pH} 4.5$ and temperature of $30{ }^{\circ} \mathrm{C}$. It was found that the reducing sugar of $98.3 \mathrm{~g} / \mathrm{L}$ could be hydrolyzed by Stargen level $100 \mathrm{mg}$ on $10 \%(\mathrm{w} / \mathrm{v})$ starch. Also reported by Yussof et al. [20], that the hydrolysis time of 8 to $24 \mathrm{~h}$ hydrolysis native tapioca starch increases reducing sugar, as indi-

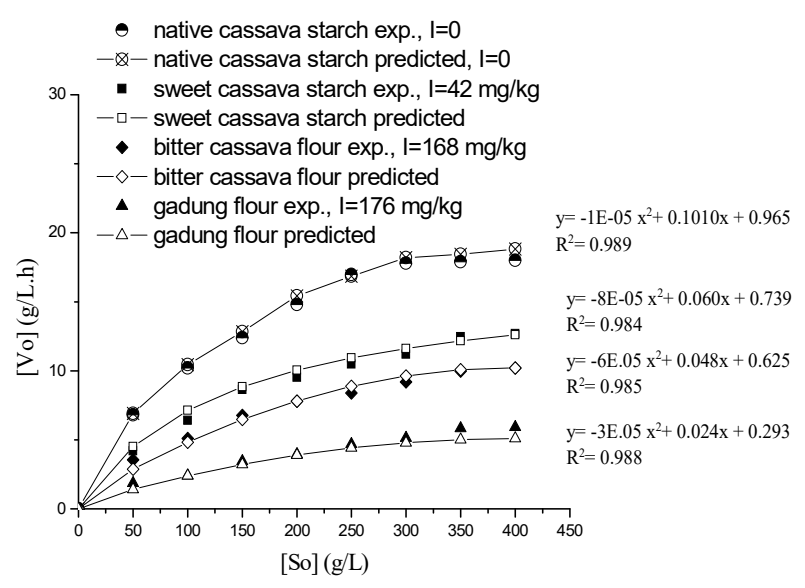

Figure 3. Effect of initial sweet cassava starch, bitter cassava and gadung flours at concentration (the range $50-400 \mathrm{~g} / \mathrm{L}$ ) on initial velocity of enzyme ( $\left.\mathrm{pH} 4,30^{\circ} \mathrm{C}\right)$ cated by increasing dextrose equivalent (DE) 18 to $35.7 \%$.

\subsection{Effect of sweet cassava starch, bitter cassava, and gadung flours on initial ac- tivity of enzyme}

Effect of initial sweet cassava starch, bitter cassava, and gadung flours at concentration of 50-400 g/L on initial activity of enzyme $(\mathrm{pH} 4$, $30{ }^{\circ} \mathrm{C}$ ) was investigated. As shown in Figure 3, the relationship of initial activity of enzyme to substrate concentration frequently assumes the form of saturation kinetics. It was observed that the initial activity of enzyme increased with increasing initial sweet cassava starch, bitter cassava and gadung flours concentration up to $400 \mathrm{~g} / \mathrm{L}$. The initial activity of the enzymes increased from 4.64 to $12.66 \mathrm{~g} / \mathrm{L} . \mathrm{h}$ (sweet cassava starch), 3.56 to $10.20 \mathrm{~g} / \mathrm{L} . \mathrm{h}$ (bitter cassava flour), and 1.99 to $5.75 \mathrm{~g} / \mathrm{L} . \mathrm{h}$ (gadung flour). The straight lines all passed then origin, and the slope was decreased with increasing concentration of cyanide in tubers. These result suggested that the inhibition of cyanide on GSHE activity was reversible. Adam [8] were also reported that the cyanide, probably in the undissociated, is shown to be a weak competitive inhibitor with inhibitor constant $K_{I}=1.54 \times 10^{-3} \mathrm{M} \mathrm{KCN}$.

\subsection{Determination of kinetics parameters and types of reversible inhibitions}

The Michaelis-Menten equation can be linearized in double-reciprocal form [21]. A plot of $1 / v_{0}$ versus $1 /\left[S_{0}\right]$ yields a linear line with a slope of $K_{m} / V_{\max }$ and y-axis intercept $1 / V_{\max }$. As shown in Table 2 , the maximum rate $\left(V_{\max }\right)$ and saturation constant $\left(K_{m}\right)$ of sweet cassava starch, bitter cassava and gadung flours were obtained. The effect of cyanide on the activity of GSHE was investigated by the equations (4-6) that were derived for competitive, noncompetitive and uncompetitive inhibition. The computer program Excel 7.0 was used to solve the equations (4-6) by minimizing the mean square of residuals. The inhibition constants for the sweet cassava starch, bitter cassava

Table 2. Comparison of the maximum velocity and the saturation constans obtained in the sweet cassava starch, bitter cassava and gadung flours at $\mathrm{pH} 4$ and temperature of $30^{\circ} \mathrm{C}$

\begin{tabular}{lcccc}
\hline \multicolumn{1}{c}{ Substrates } & $K_{m} / V_{\max },(\mathrm{h})$ & $V_{\max }(\mathrm{g} / \mathrm{L} \cdot \mathrm{h})$ & $K_{m}(\mathrm{~g} / \mathrm{L})$ & Percentage of error (\%) \\
\hline Sweet cassava starch & 8.25 & 16.95 & 139.84 & 2.85 \\
Bitter cassava flour & 10.61 & 13.33 & 141.43 & 2.84 \\
Gadung flour & 18.89 & 7.46 & 140.92 & 4.05 \\
\hline
\end{tabular}


and gadung flours of cyanide content 42,168 , and $176 \mathrm{mg} / \mathrm{kg}$ from experimental for the activity of GSHE data were calculated. The non-competitive inhibition model described the experimental activity of GSHE rate better than competitive and uncompetitive inhibition models. A plot of $1 / v_{0}$ versus $1 /\left[S_{0}\right]$ gives a family straight line with a positive intercept at the $\mathrm{y}$-axis, which indicates that the cyanide is a noncompetitive inhibitor of the enzyme (Figure 4).

The above results suggest that the inhibitor only binds to free enzyme rather than enzymesubstrate complex, the relative percentage error between the experimental and predicted activity of GSHE rate using non-competitive inhibition model for sweet cassava starch was obtained to be $2.85 \%$, while for bitter cassava and gadung flours can be shown in Table 2. To obtained the value of $K_{I}$ can be determined as the intercept in Figure 5 . The $K_{I}$ value was 0.0317 .

\section{Conclusions}

The results clearly showed that the cyanide gives an inhibitory effect on the enzymatic hydrolysis of sweet cassava starch, bitter cassava and gadung flours using GSHE at $\mathrm{pH} 4$ and temperature of $30{ }^{\circ} \mathrm{C}$. Increasing of cyanide concentration during hydrolysis process of sweet cassava starch, bitter cassava, and gadung flours decreased $V_{\max }$ significantly. The Michaelis-Menten constants $\left(K_{m}\right)$ for these three substrates were determined as 139.84 , 141.43 , and $140.97 \mathrm{~g} / \mathrm{L}$ for sweet cassava starch, bitter cassava, and gadung flours, while

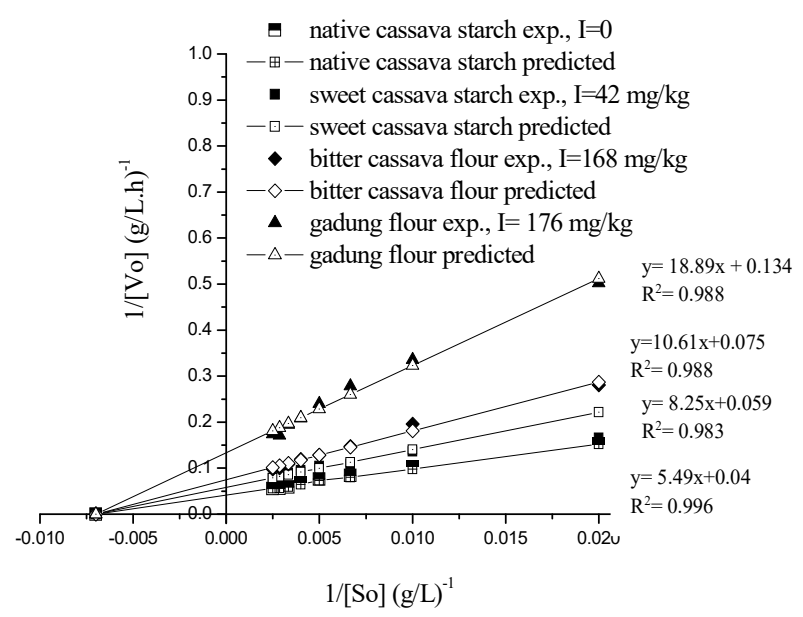

Figure 4. Lineweaver-Burk plots for sweet cassava starch, bitter cassava and gadung flours at enzyme concentration of $1.5 \%(\mathrm{w} / \mathrm{w}), \mathrm{pH} 4$, and temperature of $30^{\circ} \mathrm{C}$ the value of $K_{m} / V_{\max }$ was calculated as 8.25 , 10.61, and $18.89 \mathrm{~h}$, respectively. Based on the Lineweaver-Burk plot, the sweet cassava starch, the bitter cassava, and the gadung flours $(50-400 \mathrm{~g} / \mathrm{L})$ with cyanide concentration of 42,168 , and $176 \mathrm{mg} / \mathrm{kg}$, respectively can be classified as a noncompetitive inhibition, with $K_{I}$ value of 0.0317 .

\section{References}

[1] Bradbury, J.H., Holloway, W.D., (1988). Chemistry of Tropical Root Crops: Significance for Nutrition and Agriculture in the Pacific. Australian Centre for International Agricultural Research, Monograph No. 6, Canberra, Australia.

[2] Cock, J. (1985). Cassava: New Potential for a Neglected Crop. Westview Press, Boulder Co., London, 191.

[3] Lambri, M., Fumi, M.D., Roda, A., de Faveri, D.M., (2013). Improved Processing Methods to Reduce the Total Cyanide Content of Cassava Roots from Burundi, African Journal of Biotechnology, 19: 2685-2691.

[4] Djazuli, M. and Bradbury, J.H. (1999). Cyanogen Content of Cassava Roots and Flour in Indonesia, Food Chemistry, 65: 523525.

[5] Bradbury, J.H., Egan, S.V., Lynch, M.J. (1991). Analysis of Cyanide in Cassava Using Acid Hydrolysis of Cyanogenic Glucosides, Journal of the Science of Food and Agriculture, 55: 277-290.

[6] Nashriyah, M., Nornasuha, Y., Salmah, T., Norhayati, N., Rohaizad, M. (2010). Dioscorea hispida Dennst (Dioscoreaceae): An overview,

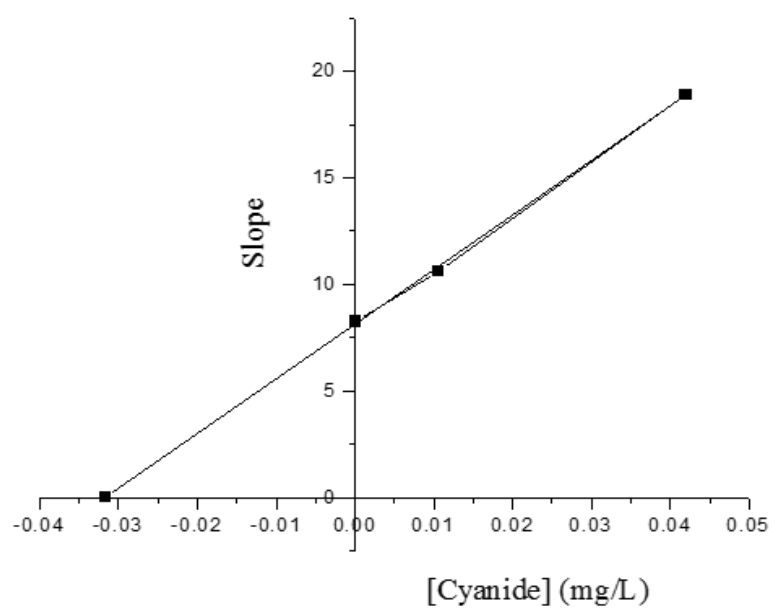

Figure 5. Determination of the inhibitor constants $\left(K_{I}\right)$ for a noncompetitive inhibitor and the value of $K_{I}$ is determined from the $x$ intercept of the line 


\section{Bulletin UniSZA, 4: 12-13.}

[7] Bhattacharyya, S.S., Mandal, S.K. (2008). In vitro Studies Demonstrate Anti-Cancer Activity of an Alkaloid of a Plant (Gelsimium sempervirens), Experimental Biology and Medicine, 12: 1591-601.

[8] Adams, J.B. (1989). Inhibition of Green Bean Lipoxygenase by Cyanide. Food Chemistry, 31: $243-250$.

[9] Parashar, A., Venkatachalam, A., Gideon, D.A., Manoj, K.M. (2014). Cyanide does more to inhibit heme enzymes, than merely serving as an avtive-site ligand. Biochemical and Biophysical Research Communications, 435: 190193.

[10] Genencor (2009) STARGENTM 002: Granular Starch Hydrolyzing Enzyme for Ethanol Production.

[11] Lehninger A.L. (2008). Principles of Biochemistry, 5 th. W.H. Freeman, New York. p.194.

[12] Lineweaver, H., Burk, D. (1934). The Determination of Enzyme Dissociation Constants, Journal of the American Chemical Society, 56: 658-666.

[13] Fange, D., Lovmar, M., Michael, Y., Ehrenberg, M. (2011). Identification of Enzyme Inhibitory Mechanisms from Steady-State Kinetics, Biochimie, 93: 1623-1629.

[14] Mc Cleary, B.V., Mc Nally, M., Rossister, P. (2002). Measurement of Resistant Starch by Enzymatic Digestion in Starch and Selected Plant Materials: Collaborative Study. Journal of AOAC International, 85: 1103-1111.
[15] AOAC. (2005). Official Methods of Analysis. 18th eds. Association of Official Analytical Chemists; Arlington, VA, USA.

[16] Miller, G.L. (1959). Use of Dinitrosalycilic Acid for Determining Reducing Sugar, Analytical Chemistry, 31: 426-428.

[17] Maisero, S.S., Peretti, A., Trierweiler L.F. (2014). Simultaneous Cold Hydrolysis and Fermentation of Fresh Sweet Potato. Biomass and Bioenergy, 70: 174-183.

[18] Copeland, R.A. (2000). Enzymes: A Practical Introduction to Structure, Mechanism and Data Analysis. $2^{\text {nd }}$ eds. John Wiley, New York; Chichester.

[19] Shanavas, S., Padmaja, G., Moorthy, S.N., Sajeev, M.S., Sheriff, J.T. (2010). Process Optimization for Bioethanol Production from Cassava Starch Using Novel Eco-Friendly Enzymes. Biomass and Bioenergy, 35: 901909.

[20] Yussof, N.S., Utra, U., Alias, A.K. (2013). Hydrolysis of native and cross-linked corn, tapioca, and sweet potato starches at subgelatination temperature using a mixture of amylolytic enzymes. Starch/Starke, (65): 285295.

[21] Michaelis, L., Menten, M. (1913). Die kinetik der invertinwirkung, Biochemistry Zeitung, 49: 333-369.

Selected and Revised Papers from The 2nd International Seminar on Chemistry (ISoC 2016) (Surabaya, 26-27 July 2016) (http://chem.its.ac.id/isoc-2016/) after Peer-reviewed by Scientific Committee of ISoC 2016 and Peer-Reviewers of BCREC journal 